\title{
Preparing Team-Taught Lessons Through a Model of ICC Development
}

\section{Bunya Suzuki \\ Lancaster University}

\section{Reference Data:}

Suzuki, B. (2019). Preparing team-taught lessons through a model of ICC development. In P. Clements, A. Krause, \& P. Bennett (Eds.), Diversity and inclusion. Tokyo: JALT.

In this paper I reflect on applying a model of ICC (intercultural communication competence) development (Brown, 2013) towards preparing team-taught classes and conducting lessons between assistant language teachers (ALTs) and Japanese teachers of English (JTEs) for 1st-year junior high school (JHS) students and discuss its implications for professional development. After summarizing the background and four levels of this model, I will clarify how and why this model was applied to create team-taught lessons. I will then describe the teachers' reflections on their work from interviews, which indicated the overall satisfaction of both ALTs and JTEs. This was accomplished by their going beyond their cultural differences, recognizing each other's strengths and weaknesses, and helping each other. However, disagreement over time management and lesson aims became evident due to a difference in the number of lessons they taught and in their professional status, which is a practical issue beyond the scope of this model.

本稿は、東京のある中学校にて外国語指導助手 (ALT) と日本人英語教諭(JTE) のチームワークにおいてICC (異文化コミュ 二ケーション能力)の発展モデル (Brown, 2013)を授業準備と実践に用いたことを振り返り、教員養成への示唆を論じる。まず このモデルの背景と4つのレベルをまとめ、このモデルをどのように、なぜ、中学1年生のチームティーチングの授業作成に用 いたかを明らかにする。次にALTとJTEへのインタビューを基に準備と実践を振り返る。それによると、双方ともお互いの文化 の違いを乗り越えお互いの強みと弱みを認識し助け合えたことに全体的な满足感を示していたが授業の時間管理と目的 において音貝の相椲が見られた。ALTとUTEの参加する授業回数や雇用体系の違いといったこのモデルの範囲外となる実務 的な問題がこの縣念の原因となっていた。

t has now been 30 years since the launch of the JET (Japan Exchange and Teaching) L Programme, in which young native English-speaking college graduates have been hired as assistant language teachers (ALTs) to team-teach with Japanese teachers of
English (JTEs) and to participate in internationalization initiatives and foreign language education (CLAIR, 2015; Crooks, 2001). The benefits of the JET Programme are such that working with ALTs has increased JTEs' opportunities to use English (Gorsuch, 2002), and students have become more actively involved in communicative activities as teachers mostly speak English (Sakui, 2004, 2007). Johannes (2012) found that many high school students enjoy communication with ALTs and value the communicative nature of teamtaught lessons to improve their English.

However, the JET programme is not without challenges. Many ALTs do not possess teaching qualifications or a pedagogic background prior to application, and it is questionable whether these unqualified and inexperienced ALTs have the capacity to improve the quality of language classes (Ohtani, 2010; Wang \& Lin, 2013). Moreover, the language barrier and a lack of coordination with JTE's have been raised as concerns, bringing about negative impacts on the team-teaching process (Kano et al., 2016; Ohtani, 2010). At junior high schools (JHSs), Kano et al. (2016) found that ALTs express great dissatisfaction with their low degree of participation in planning and their roles in the classroom.

Being a full-time JTE at a secondary school teacher myself, what I initially found valuable from working with ALTs was their unique language learning experiences and life histories that brought fresh learning styles and viewpoints into the classroom. However, the challenges were that ALTs possessed relatively low knowledge of Japanese educational culture and lacked political power due to their status as assistants, making them rather powerless at school (Miyazato, 2009). Thus, I have had a strong desire to improve the situation and make the most of team teaching. In this paper, I will briefly introduce how the model of ICC (intercultural communication competence) development (Brown, 2013) provided me with valuable insights for our teamwork, describe how it initiated changes in how ALTs and JTEs work together at our secondary school, and reflect on those changes through interviews with teachers. 
A Model of ICC (Intercultural Communication Competence)

\section{Development}

\section{Background}

Drawing upon the characteristics of team teaching conducted in the East Asia region, Carless (2006) identified three enabling features necessary for team teaching: pedagogic aspects, logistical aspects, and interpersonal aspects. Of the three, he found that successful team teaching relies to a large extent on the following interpersonal aspects: sensitivity and goodwill towards each other, developing relationships both during and outside lessons, eagerness to overlook minor issues, eagerness to compromise, respect from ALTs towards well-established cultural norms in classrooms, and progression of personnel with time. Brown (2013) assumed that the interpersonal aspects were highlighted in Carless because ALTs' and JTEs' different cultural backgrounds can lead to difficulties, but the other two aspects can be improved provided that the teachers can collaborate. Thus, Brown stated that the capacity to communicate across cultures, that is intercultural communication competence (ICC), should be investigated before pedagogic or logistical aspects. There being very few models of ICC development designed for team teaching, much less for ALTs and JTEs, Brown suggested the following model to address this gap and promote ICC

\section{The Four Levels}

This model draws upon Young's (1997) theory of asymmetrical reciprocity: Each member has a different life history and social situation, and thus others' viewpoints are to be understood through dialogue and questions, rather than trying to be empathetic to their viewpoints. Brown (2013) took this asymmetrical relationship between ALTs and JTEs into account in addressing the four levels for ICC development.

Level 1: Perceiving Differences Asymmetrically

ALTs and JTEs come from different cultural backgrounds and may see the world differently. In order to reduce misunderstandings, they need to acknowledge that there are viewpoints that go beyond their own culture and understandings.

Level 2: Considering the Value and Limitations of Stereotypes In acknowledging the uniqueness of each other's culture, stereotypical knowledge and views of the other's context may be a useful tool for initial understandings. However, culture is constructed and transformed across time and space. Thus, ALTs and JTEs should not be too reliant on stereotypes, but should be flexible and maintain doubts about the accuracy of stereotypes in understanding each other.

\section{Level 3: Communicating in Intervals}

An interval between the giving and taking of responses during communication is essential in that it enables participants to analyze the communicative actions that are and are not successful. Here, participants identify the culturally different characteristics and values, leading to a genuine interest towards each other.

\section{Level 4: Circulating Forward Toward Wonder}

This genuine interest is expressed through questions and the desire to understand each other. Having these questions and desires evolves into mutual respect and recognition of the importance of diversity, which lead to an equal relationship of participants that remains asymmetrical. As this was initially illustrated in the first level, the four levels of this model are in a cyclical pattern. Thus, these four levels are to be considered repeatedly in order to accomplish communication through each other's culture.

To overcome the difference of cultural knowledge of Japan and maximize ALTs' and JTEs' potential in team teaching, I consider that it is important for JTEs to acknowledge that "we" are different and work towards understanding each other, rather than thinking that "they" are different and imposing the "Japanese way of doing" on ALTs. Thus, this model of ICC development has become a vehicle for redesigning interactions between ALTs and JTEs to support effective intercultural communication, with the aim of making team teaching more productive and satisfying. The next section will illustrate how this model has been practiced.

Method

\section{Context and Participants}

The model of ICC development was practiced at a private boys' junior and senior high school in Tokyo, where I also work as a full-time English teacher. Alongside 15 fulltime and four part-time JTEs, there were two American-born ALTs, Peter and Eric (all names are pseudonyms). They were both in their 20s and were hired through the JET programme 2 years prior to this study, when the school started to use the programme. Unlike the JTEs with a fixed teaching schedule, the schedule of the ALTs prior to this 
study had been fluid in that they were called by the JTEs for team teaching when necessary, except for their weekly team teaching of 2nd-year high school students.

The model was applied towards six English classes for 1st-year JHS students (ages 1213), who were mostly Japanese nationals and beginner learners of English. English classes met five times a week: four classes were solo-taught by JTEs and the other was a class team-taught by ALTs and JTEs that had been newly introduced in the year of the study. Four full-time JTEs, including Makoto, Yoshio, and I as the class convener, were in charge of these English classes.

Prior to applying this model, team teaching was a new practice for this school, and the JTEs did not have much prior knowledge or fixed methods of team teaching. Judging from my personal communication with other JTEs, cultural gaps between ALTs and JTEs seem to have been a barrier to working together and creating satisfactory lessons. That is, they each had different teaching methods and expectations towards students that were based on their own language learning (and teaching) experiences. These differences made it difficult to reach agreement, which seems to have made JTEs reluctant about team teaching. Thus, we were at the stage of wondering how to overcome these differences which led me to apply this model.

\section{Applying the Model}

A detailed procedure for preparing each lesson was detailed in Suzuki (2018), so I will provide here how the model helped us prepare team-taught lessons. In my initial meeting with the ALTs to open the discussion about 1st-year JHS English classes, I did not explicitly talk about the model of ICC development, but started with the following message:

I want to work with you, not because you are native speakers of English, but to enrich the language classroom with more teachers to support students' work and create more materials from a variety of viewpoints. You are not "guests." (Suzuki, 2018, p. 66)

This message was a key to applying this model, as its aim was to communicate my desire to go beyond the cultural barriers and maximize the ALTs' potential to improve team teaching. Thus, this message was explicitly shared with the other JTEs who were teaching the 1st-year JHS students, although I did not clearly talk about the model. Then, the ALTs and I held several meetings to prepare the lessons, which I carefully designed to apply the four levels of the model. At the beginning of each term, we went over the linguistic features to be covered and discussed the lesson aims of each teamtaught lesson. Next, the ALTs created worksheets and lesson plans to be used in class. My idea here was that though the ALTs were native speakers of English, they each had their own life history as learners and users of other language(s) to apply to their teaching, which were different from my own experiences in Japan (Level 1), and different from the stereotypical assumption that native speakers are monolingual and cannot teach language (Level 2; Ellis, 2016). In addition, I thought that asking them to express their creativity would lead to their positive engagement in lesson planning, and thus towards the English classes and students.

We then held a meeting each week, going over and revising the worksheets and lesson plans. This was the most challenging part to negotiate, as we each had unique sociocultural identities and teaching practices (Duff \& Uchida, 1997) that made it unrealistic to reach a perfect agreement on what we wanted to do in class. Having a meeting each week helped overcome this uneasiness, as we had multiple intervals (Level 3 ) to gradually get to know each other and become interested in what we each had to offer, leading to more questions and mutual respect (Level 4), which helped us progress towards accomplishing our ultimate goal: conducting successful lessons.

Next, the worksheets and lesson plans were sent to the other three JTEs, and they had meetings with the ALTs respectively. This was the end of the preparation stage, and the team-taught lessons were then conducted. The ALTs mainly led the lessons, and each JTE played the role of a supporter; the JTEs became the ALTs' partners in providing students with an example of authentic communication and helped students when they seemed to be struggling. After class, we provided each other with comments on what we thought of the lesson. This proved to be valuable for our professional development as a team and the cyclical path in applying this model, which was to once again start preparing and meeting for our next team-taught lesson.

\section{Reflections}

I conducted semistructured teacher interviews at the end of the school year, using questions that were adapted from Brown (2016; see Appendix). The interviews were in English with the ALTs and in Japanese with the JTEs (the interview transcripts below are translated by the author). They were conducted to gain a further understanding of ALTs' and JTEs' reflections on how the message above changed team teaching and which points were in need of improvement. 


\section{How Team Teaching Changed}

When asked to comment on his general impression, Eric expressed his excitement as the message became a catalyst for his own ideas being used in class. In addition, he acknowledged that JTEs knew more about the students' background and common difficulties in learning English (see Carless, 2006), he recognized his weaknesses as an assistant, and he found that asking JTEs for help was not a frustrating experience:

When I found that you [the author] wanted us to actually plan the lessons or lead the activities, those were kind of a refreshing take.

As an assistant teacher, it was nice to see the ideas that I came up with, with your [author's] help, kind of being implemented into the classroom.

You [JTEs] are there to assist me and helping them learn. And then when there are parts that are maybe too difficult for them to understand in English you are able to help them better understand through examples, or if you needed to use Japanese.

Peter also expressed his satisfaction, starting from his reflections on the difficulties he faced in the previous year. He commented that he was able to accomplish much more than he had previously for the students and explained that the meetings that I had designed through the model were beneficial, as they enabled him to negotiate what to expect through team teaching:

There was the question of how to use me.... So, as is common in many schools, I might be a tape recorder, help with pronunciation, just help to grade, look at students' writing, watch them do a speech, very kind of passive, not very hands-on, I was sort of a guest.

We were able to introduce many things in their Chu-ichi [1st-year junior high] class that could form a good foundation for their future English learning.

It [The meeting] was good that we could be on the same page, and it gave us time to discuss things to sort of negotiate a good classroom, also to sort of negotiate what we expected, what were the expectations for the Japanese English teacher, what were the expectations for the ALT.

Makoto explained that the message became a catalyst to acknowledge the differences of strengths and weaknesses between himself and the ALTs, leading him to try to make the most of what ALTs had when they came to class. He explained that he gradually got used to his role in class as a "supporter," finding it natural to help ALTs when he foresaw or found difficulties during class:

When an ALT comes, I want to bring out their best and have them do what I can't do myself.

When I teach, students don't have much freedom to express themselves, but when the ALTs come, students have more activities and freedom to do so.

The more experience I gained in working with them, the more I got used to my role to make team teaching work, such as having ALTs speak as much English as possible while I translate difficult parts into Japanese and walk around class to help weaker students.

Yoshio also expressed that the message enabled him to recognize the differences between himself and the ALTs and reconsider the potential of team teaching:

It became a great opportunity to reflect on maximizing our roles in the classroom.

We can provide students with a model dialogue.

ALTs can teach cultural information through their unique background ... .JTEs are responsible to offer clear learning outcomes to the students .... We talk about our strengths and weaknesses before class and negotiate our roles in the classroom.

As such, through the interviews, it became evident that the model became a catalyst to encourage the overall satisfaction of ALTs and JTEs, as the message and meetings enabled ALTs to negotiate what they wanted to do in class, JTEs to reconsider the potential of team teaching, and made it natural for all of them to use each other's strengths and help each other when necessary.

\section{A Point in Need of Improvement}

However, it became evident through the interviews with both ALTs and JTEs that there were issues of time management and what to accomplish in the lesson. Peter commented as follows:

Just time management. We both had things we wanted to cover, things that [we had] picked off on from the last lesson that was maybe solo-taught to review something or quiz or give ... do some administrative task, and then to do what we actually needed to do for that day. 
Although he stated that this became less a challenge as time passed with communication and flexibility of schedule, he mentioned that the JTE's decision "has to be a priority," concerning the difference in the number of lessons that they are involved in:

There's not so much that you can do, because, in most, in almost all cases, the JTE is teaching the students every English class, they will always be there, they have a better idea holistically of what the students are expected to do from the beginning of the term to the end.

The JTEs also explained that it was not easy to reach a common lesson aim with ALTs:

It was sometimes difficult when there was a gap between their [ALTs'] plans and what the JTE-taught lessons covered and/or what the students could do. (Makoto)

There were times when the final goal was not agreed upon, whether it was accomplishment of the task or language acquisition through the task. (Yoshio)

When I asked the JTEs how they dealt with this challenge, they stated that they did not communicate this much with the ALTs:

Team teaching is only once a week, so I let their decisions become the priority. (Makoto)

They are assistants, so I didn't ask that much. (Yoshio)

As such, time management, or agreeing on lesson aims, was found to be an issue for both ALTs and JTEs. Interview data revealed that the number of team-taught lessons during the week and the difference of status prevented the teachers from discussing this issue, suggesting a further need to find how to improve this situation.

\section{Discussion}

Through the interview data, it seems that the model of ICC development led to an overall satisfaction for ALTs and JTEs about the team-taught lessons. Prior to applying the model, cultural gaps between ALTs and JTEs seem to have prevented ALTs and JTEs from working together and creating satisfactory lessons, leading to few opportunities for ALTs to feel that they were being actively used. Faced with the need to improve this situation, I referred to the model to develop my key message for developing the relationship between ALTs and JTEs, "to enrich the language classroom with more teachers to support students' work and create more materials from a variety of viewpoints." This message became a catalyst to acknowledge the strengths and weaknesses that ALTs and JTEs have, recognize their roles in class, and naturally support each other. In addition, the ALTs were able to express their creativity in planning lessons, and through the meetings that I designed that followed the four levels of the model, we were able to negotiate what we wanted to do in class and make the most of each other's abilities. As a result, ALTs considered their work and achievements to be fulfilling, and JTEs found the value of applying their strengths to class.

However, applying the model revealed another issue that we were not able to sort out during this practice: time management, or agreeing on lesson aims. In the interviews, the teachers stated that the difference in number of lessons they taught a week and difference in status prevented them from negotiating this issue, which led to one having to follow what the other was doing, sometimes without agreement. The issue here was not so much a cultural one but a practical one. Our school had two ALTs but 19 JTEs, and it was impossible for ALTs to attend every English class. In addition, as ALTs are "assistants," the extent to which ALTs are expected to participate or share their knowledge is not likely to be the same as in the case of qualified teachers.

As such, this was a practical issue that was beyond the scope of ICC development, suggesting a further need to develop methods to achieve satisfactory teamwork. More reflections on educational practices through this model are necessary to understand its practical limitations and develop alternative resolutions. Nevertheless, this mode became a catalyst for 2nd-year ALTs and JTEs with little experience in team teaching to understand each other and strive to maximize each other's potential. In addition, as an ALT's term of service is 5 years at most and JTEs may also transfer from or into other schools, there should be numerous cases where ALTs and JTEs need to form new teams and work together. Thus, this model has the potential to be beneficial in many cases for ALTs and JTEs to go beyond their different cultural characteristics and begin successful team teaching.

\section{Conclusion}

Through working with ALTs, I have noticed that if JTEs can overcome cultural clashes, team teaching has the potential of bringing into the classroom an ALT's unique life history and culture, which can enrich the classroom with a perspective different from that of the JTE. In order to facilitate teamwork, I have found that applying a model of ICC development can become a strong foundation for ALTs and JTEs to complement each other and make the most of team teaching. Although interview data revealed an additional difficulty of reaching an agreement on time management and lesson aims, a 
discussion of this is beyond the scope of this paper as it was due to a practical difference in the number of lessons that ALTs and JTEs teach and in their respective professional status. Alternative methods remain to be addressed to deal with noncultural issues. In addition, as this article is only a reflection on educational practices at a particular school, more practical reports are awaited to grasp further the strengths and weaknesses of this model and reveal the noncultural issues that are necessary to sort out. I hope that this will enable the discussion of teamwork between ALTs and JTEs and develop further ideas to improve team teaching.

\section{Bio Data}

Bunya Suzuki is a PhD candidate at Lancaster University and is also a full-time English teacher at a private boys' junior and senior high school in Tokyo. He is currently interested in second language socialization of Japanese learners of English and promoting a nondiscriminatory environment for all English language learners and teachers. <b.suzuki1@lancaster.ac.uk>

\section{References}

Brown, J. (2013). On the way to effective team teaching. Journal of Intercultural Communication, 33 Retrieved from http://immi.se/intercultural

Brown, J. (2016). Team teaching in the English classroom in Japan: A call for intercultural communicative competence development. Accents Asia, 8(2), 102-112.

Carless, D. R. (2006). Good practices in team teaching in Japan, South Korea and Hong Kong. System, 34(3), 341-351. https://doi.org/10.1016/j.system.2006.02.001

CLAIR. (2015). Introduction. Retrieved Nov. 18, 2017, from http://jetprogramme.org/en/about-jet/

Crooks, A. (2001). Professional development and the JET program: Insights and solutions based on the Sendai City program. JALT Journal 23(1), 31-46. Retrieved from https://jalt-publications.org/ sites/default/files/pdf-article/jj-23.1-art2.pdf

Duff, P., \& Uchida, Y. (1997). The negotiation of teachers' sociocultural identities in postsecondary EFL classrooms. TESOL Quarterly, 31(3), 451-486. https://doi.org/10.2307/3587834

Ellis, E. (2016). "I may be a native speaker but I'm not monolingual": Reimagining all teachers' linguistic identities in TESOL. TESOL Quarterly, 50(3), 597-630. https://doi.org/10.1002/ tesq. 314

Gorsuch, G. (2002). Assistant foreign language teachers in Japanese high schools: Focus on the hosting of Japanese teachers. JALT Journal, 24(1), 5-32. Retrieved from https://jalt-publications. org/sites/default/files/pdf-article/jj-24.1-art1.pdf
Johannes, A. (2012). Team teaching in Japan from the perspectives of the ALTs, the JTEs, and the students. TEFLIN Journal, 23(2), 165-182. Retrieved from http://teflin.org/journal/index.php/ journal/article/viewFile/145/137

Kano, A., Sonoda, A., Schultz, D., Usukura, A., Suga, K., \& Yasu, Y. (2016). Barriers to effective team teaching with ALTs. In P. Clements, A. Krause, \& H. Brown (Eds.), Focus on the learner (pp. 74-82). Tokyo: JALT. Retrieved from https://jalt-publications.org/sites/default/files/pdf-article/jalt2015pcp_011.pdf

Miyazato, K. (2009). Power-sharing between NS and NNS teachers: Linguistically powerful AETs vs. culturally powerful JTEs. JALT Journal, 31(1), 35-62. Retrieved from https://jalt-publications org/sites/default/files/pdf-article/art2_6.pdf

Ohtani, C. (2010). Problems in the assistant language teacher system and English activity at Japanese public elementary schools. Educational Perspectives, 43(1\&2), 38-45.

Sakui, K. (2004). Wearing two pairs of shoes: Language teaching in Japan. ELT Journal, 58(2), 155 63. https://doi.org/10.1093/elt/58.2.155

Sakui, K. (2007). Classroom management in Japanese EFL classrooms. JALT Journal, 29(1), 41-58. Retrieved from https://jalt-publications.org/sites/default/files/pdf-article/art2_11.pdf

Suzuki, B. (2018). Implementing communicative activities into the language classroom-Reexamining the potentials of team-teaching. The IRLT Journal, 17, 64-71.

Wang, L., \& Lin, T. (2013). The representation of professionalism in native English-speaking teachers recruitment policies: A comparative study of Hong Kong, Japan, Korea and Taiwan. English Teaching: Practice and Critique, 12(3), 5-22.

Young, I.M. (1997). Intersecting voices: Dilemmas of gender, political philosophy, and policy. Princeton, NJ: Princeton.

Appendix

Interview Questions (Adapted From Brown, 2016)

In teaching 1st-year junior high school students,

1. What did you think of the team-taught lessons?

2. What did you think of having the ALTs create worksheets and lesson plans?

3. In what ways do you believe team teaching assisted in teaching English?

4. What are certain things that both the ALTs and JTEs did in order to create and teach a successful lesson as a teaching team?

5. What difficulties and problems did team teaching cause? Is there anything that was done / could have been done to decrease or prevent these problems from occurring? 
6. If you were given the opportunity to train other teachers in team teaching, what are some key elements you would focus on? Why?

7. What about team teaching did you personally find to be most beneficial and rewarding? What did you find to be most problematic and challenging? 